\title{
Heat pump system efficiency comparison of different renewable energy sources - A family house case study in the Zagreb city area
}

The Mining-Geology-Petroleum Engineering Bulletin UDC: $622.1: 627.8$

DOI: $10.17794 /$ rgn.2018.5.2

Preliminary communication

\author{
Marija Macenic ${ }^{{ }^{*}}$; Tomislav Kurevija ${ }^{2}$; Josipa Kapuralić ${ }^{3}$ \\ ${ }^{1,2,3}$ Faculty of Mining, Geology and Petroleum Engineering, University of Zagreb, Pierottijeva 6, Zagreb, Croatia
}

\begin{abstract}
The wider Zagreb city area, the capital city of the Republic of Croatia, has significant potential for major implementation of geothermal heat pump systems in not just the residential sector, but in the commercial sector as well. Geothermal heat pumps often cumulatively describe different earth energy heat exchanger installations, from groundwater up to shallow ground horizontal and borehole heat exchanger installations. The Zagreb area is especially favourable for both hydrogeological and thermogeological parameters, which allows for the implementation of different designs for residential and commercial heating and cooling. An analysis of comparative energy and economic advantages of heating and cooling with heat pump systems (air, ground or groundwater) was made for the capital city of Zagreb. Since heat pump systems in residential areas are always a higher-class investment, there is often a need for year-round heating since projects increasingly incorporate outdoor swimming pools. Up till now, many authors investigated a comparison of winter heating energy costs for different heat pump systems. However, outdoor swimming pools sometimes consume as much heating energy during the spring-summer-autumn seasons, as do houses in the autumn-winter-spring seasons. Since air temperatures during the spring-summer seasons are much more favourable than sub-cooled ground or groundwater temperatures, air-source heat pumps when used during the whole year for heating, could offset an economically unfavourable coefficient of performance (COP) during the coldest days of winter. On a real residential home, currently in the construction phase, techno-economic analysis was performed comparing the seasonal performance factor (SPF) for different heat pump systems during year-round heating.
\end{abstract}

\section{Keywords:}

shallow geothermal energy, heat pump, thermogeology, borehole heat exchanger, groundwater.

\section{Introduction}

The most common type of heat pump is the AirSource Heat Pump (ASHP), which transfers heat between the indoor and outside air. Since air temperatures have significant amplitudes during the year, for ASHP to be able to satisfy peak heating load, hourly air temperatures must be known for the entire year. In somewhat colder climates, temperatures drop below $0^{\circ} \mathrm{C}$ in the winter so special care must be taken when sizing heat pumps (HP). It is common to express the heating capacity of a certain model according to the EN14511:2004 standard, usually in values of $30 / 35^{\circ} \mathrm{C}$ (internal exchanger/condenser-water) and $+7^{\circ} \mathrm{C} \mathrm{DBT} /+6^{\circ} \mathrm{C}$ WBT (Dry Bulb Air Temperature and Wet Bulb Air Temperature of evaporator external exchanger for ASHP). Considering the vapor-compression refrigeration cycle of the heat pump, lowering the evaporator isotherm (drop in outside temperature below given values) will result in a decrease of heat pump heating capacity and the coefficient of performance for the compressor (COP). There-

Corresponding author: Marija Macenić

marija.macenic@rgn.hr fore, if an ASHP is installed as a monovalent system to cover the entire peak load of a building, a drop in heating capacity must be compensated with an additional source of energy, usually in the form of an electric heater. The number of working hours of an electric heater influences the seasonal performance factor of an ASHP, in function of temperature hourly distribution during the winter. Oversizing the ASHP to mitigate the heating capacity drop versus the outside temperature leads to an expensive system which can be described with a low number of full-load hours of the heat pump. Since the average air temperature in January for the city of Zagreb is $-0.8^{\circ} \mathrm{C}$, the analysed ASHP system capacity was sized for an initial set of $0^{\circ} \mathrm{C} / 35^{\circ} \mathrm{C}$ conditions. For lower temperatures during the winter, the ASHP decreases its heating capacity and this difference is supplemented with an additional electric heater.

Unlike an ASHP, general geothermal heat pumps (GHP), either ground-source heat pumps (GSHP) or ground water heat pumps (GWHP) work with much more favourable and uniform external exchanger temperatures. The term "geothermal" usually describes all kinds of ground or groundwater heat exchanger designs, 
where the heat is extracted from the ground or groundwater in the winter, or rejected to the ground or groundwater in the summer. A subgroup that describes closed loop heat exchangers, according to the standard nomenclature of ASHRAE (American Society of Heating, Refrigerating and Air-Conditioning Engineers), is abbreviated GCHP (ground-coupled heat pumps). Furthermore, it can be divided to vertical GCHP, with one or two Uloop polyethylene pipes placed in a borehole with the usual depth of $100 \mathrm{~m}$, and horizontal GCHP, which implies all sorts of designs from single pipes, multiple pipes, or coil pipes placed in narrow trenches with the usual depth of $1.5-5.0 \mathrm{~m}$. All of these ground exchanger designs, however, must be carefully planned and tested with the Thermal Response Test (TRT) to confirm heating capacity, according to thermogeology and climate parameters.

Just like borehole heat exchangers, groundwater wells must take special care in planning and sizing. Hydrogeological parameters of a local aquifer must be known, and wells need to be tested to confirm production potential and drawdown. However, there are certain limitations in the widespread use of GWHP such as; groundwater chemistry (high content of iron and manganese), higher pumping power, need for additional injection wells and strict environmental regulations near the potable water resource wells. The objective of this paper is therefore to analyse a real family house project in the wider Zagreb area, considering different renewable energy sources for a heat pump system. By implementing an hourly bin temperature, techno-economic analysis was carried out to determine operating costs of the geothermal heat pump, compared to a natural gas boiler as a common heating system.

\section{Geological and climate characteristics of the wider Zagreb city area}

To successfully plan and model an efficient geothermal heat pump system, elementary climate data and geological, hydrogeological and thermogeological data should be known, or estimated with satisfactory accuracy if there was no previous research in the area. Since geothermal heat extraction from the ground and groundwater is not abundant, a properly sized system will eliminate sub-cooling of the ground in closed geothermal loops and problems with groundwater well drawdown in open loop systems.

\subsection{Geological and hydrogeological aspects}

From geological aspects, the Zagreb and SamoborZaprešić aquifer areas consist of middle and younger Pleistocene and Holocene sediments. Middle Pleistocene is predominantly composed of gray sands and gray, red and yellow-brown silts and clays. Frequent lateral changes of gravels, sands, silts and clays occur in younger Pleistocene. Holocene is made of yellow-brown grav- els and sands with predominant limestone pebbles. During the Middle and Late Pleistocene, that area was a marshy lake while the surrounding mountains (Medvednica and Vukomeričke Gorice) were subject to intensive erosion and denudation. Eroded material is carried by streams and deposited in lakes and marshes (Velić and Saftić 1991).

At the beginning of the Holocene, climatic and tectonic processes allowed for the formation of the Sava River course, which began transporting materials from the Alpine region (Velić and Durn, 1993). The consequence of different conditions of deposition in the Holocene is distinct heterogeneity and anisotropy of the aquifer and unequal layer thickness.

Younger Holocene sediments make the first $\left(a_{1}\right)$ and second $\left(a_{2}\right)$ Sava terrace. The second Sava terrace was formed through incising of the Sava River in alluvial sediments and consists of coarse gravels and sands. After the deposition of gravels and sands of the second Sava terrace came the phase of erosion and denudation. Sava incised in its own sediments and began deposition of the first Sava terrace sediments $\left(a_{1}\right)$. It consists of coarse-grained gravels mixed with sands. Recent alluvial deposits of the Sava River consist predominantly of sands and silts, and gravel is less present. A detailed geological map of the wider city of Zagreb area is shown in Figure 1, according to (Šikić et al. 1978).

With a hydrogeological point of view, the Zagreb and Samobor-Zaprešić aquifers are alluvial unconfined aquifers with a water table in constant contact with the Sava River. Their horizontal spreading is determined by Quaternary sediments which, however, define the domain of the aquifers as seen in Figure 1. The Samobor-Zaprešic aquifer is about $15 \mathrm{~km}$ long, with an average width of 5 $\mathrm{km}$, while the Zagreb aquifer is approximately $30 \mathrm{~km}$ long, with an average width of 10-15 km.

Quaternary sediments are divided into three main units: cover deposits of the aquifer system, a Holocene shallow aquifer predominantly composed of alluvial deposits, and a deeper middle and younger Pleistocene aquifer. Differentiation between shallow and deeper aquifers is stratigraphic considering that they are hydraulically connected and form a single aquifer with a hydrogeological point of view (Parlov et al. 2012). A schematic of the hydrogeological profile with stratigraphic column of Zagreb aquifer is shown on Figure 2.

Top deposits in this area are very thin and often they are not even present, while the thickness of the Quaternary aquifer complex (gravel, sand, clay interbeds), ranges from 5 meters in the western part to 60 meters in the eastern part of the Samobor-Zaprešić aquifer and about 100 meters at the eastern part of the Zagreb aquifer (the Črnkovec area). The edges of the aquifer form, in the hydraulic sense, an impermeable boundary to the north, an inflow boundary in the west and south and an outflow boundary in the east. The general direction of flow of the groundwater is from west to the east and 


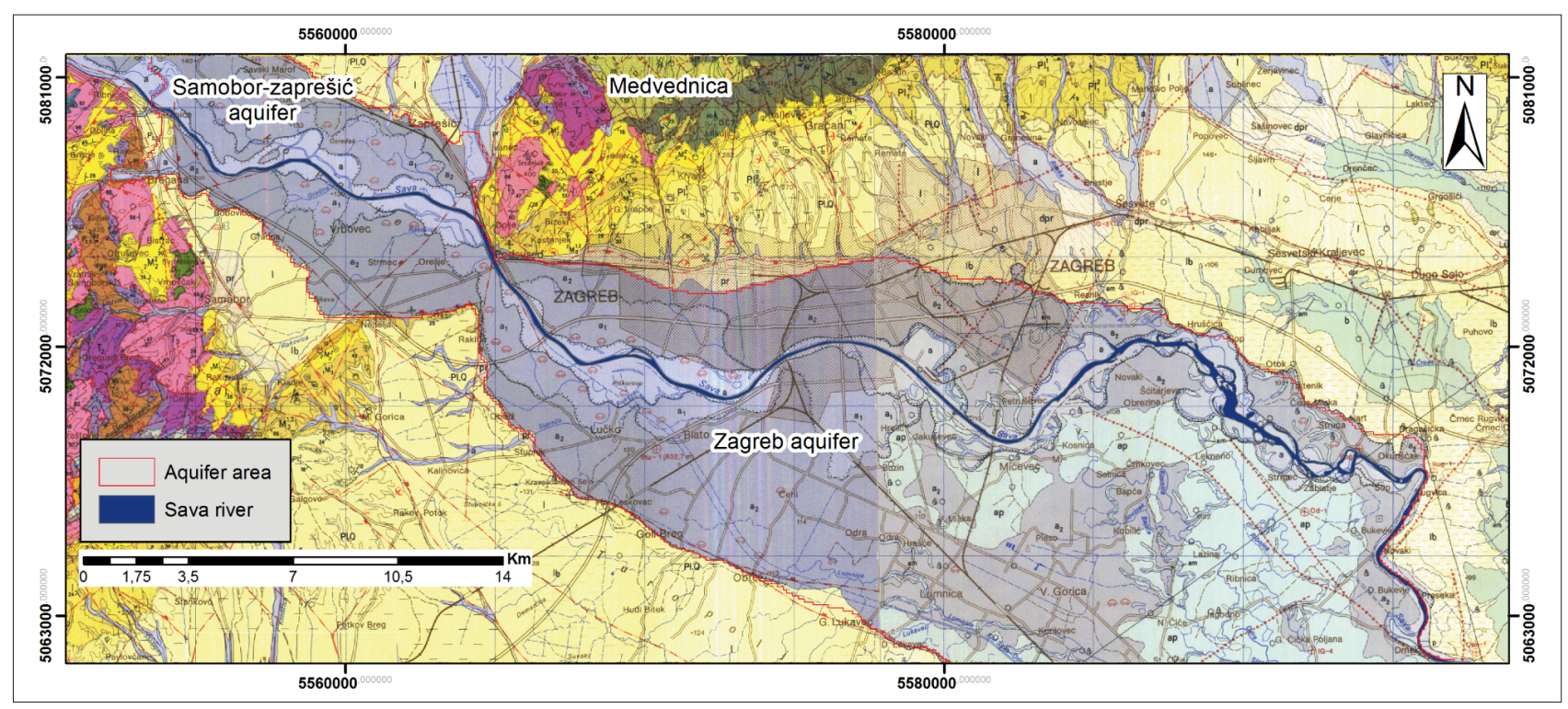

Legend: a - aluvium: gravels, sands and clays; $\mathrm{a}_{1}$ - the lowest terrace: gravels, sands and clays to a lesser extent; $\mathrm{a}_{2}$ - middle terrace: gravels and sands; $\mathrm{pr}$ - proluvium: gravels, sands and clays; 1 - clayey silt; $1 \mathrm{~b}$ - marshy loess: silty clays; Pl, $\mathrm{Q}$ - gravels, sands and clays; $\mathrm{Pl}_{1}{ }^{1}$ - marls, marly clays, sands to a lesser extent, sandstones, gravels and conglomerates (lower pont); ${ }_{2} \mathrm{M}_{3}{ }^{1,2}-$ lime marls, sands to a lesser extent, sandstones, gravels and conglomerates (upper panon); ${ }_{2} \mathrm{M}_{2}{ }^{2}$ - limestones, sandstones, lime and clayey marls (upper torton); $\mathrm{T}_{3}$ - dolomites, limestones to a lesser extent, dolomitic limestones and shales; $\mathrm{T}_{2}$ - dolomites, limestones to a lesser extent, dolomitic limestones and shales

Figure 1: Geological map of wider Zagreb area needed for development of any type of GHP system (from Šikić et al., 1978)

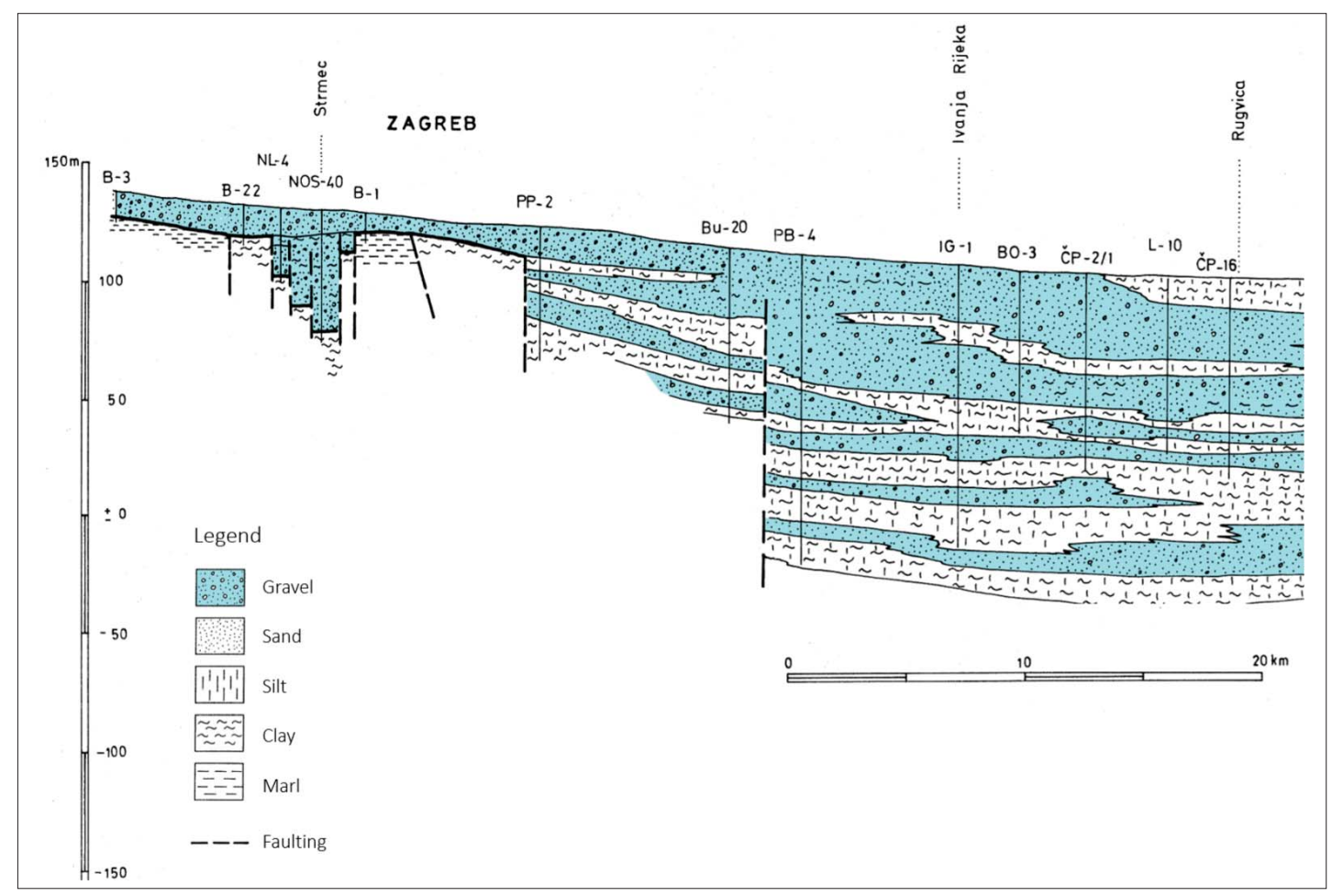

Figure 2: A schematic hydrogeological profile of the Zagreb aquifer (from Brkić, 1999)

southeast. Local directions to a large extent depend on water levels of the Sava River, which has a dominant impact on changes in groundwater level. An analysis of equipotential maps (Posavec, 2006) showed that during high waters, the Sava recharges the aquifer along the entire course in the study area, while during medium and low waters, drainage of the aquifer occurs at certain sections of the course.

In general, a hydraulic connection between the Sava River and aquifers is very strong since, along the Sava flow through the Zagreb and Samobor-Zaprešić areas, the river cuts into the alluvial aquifer Holocene deposits 


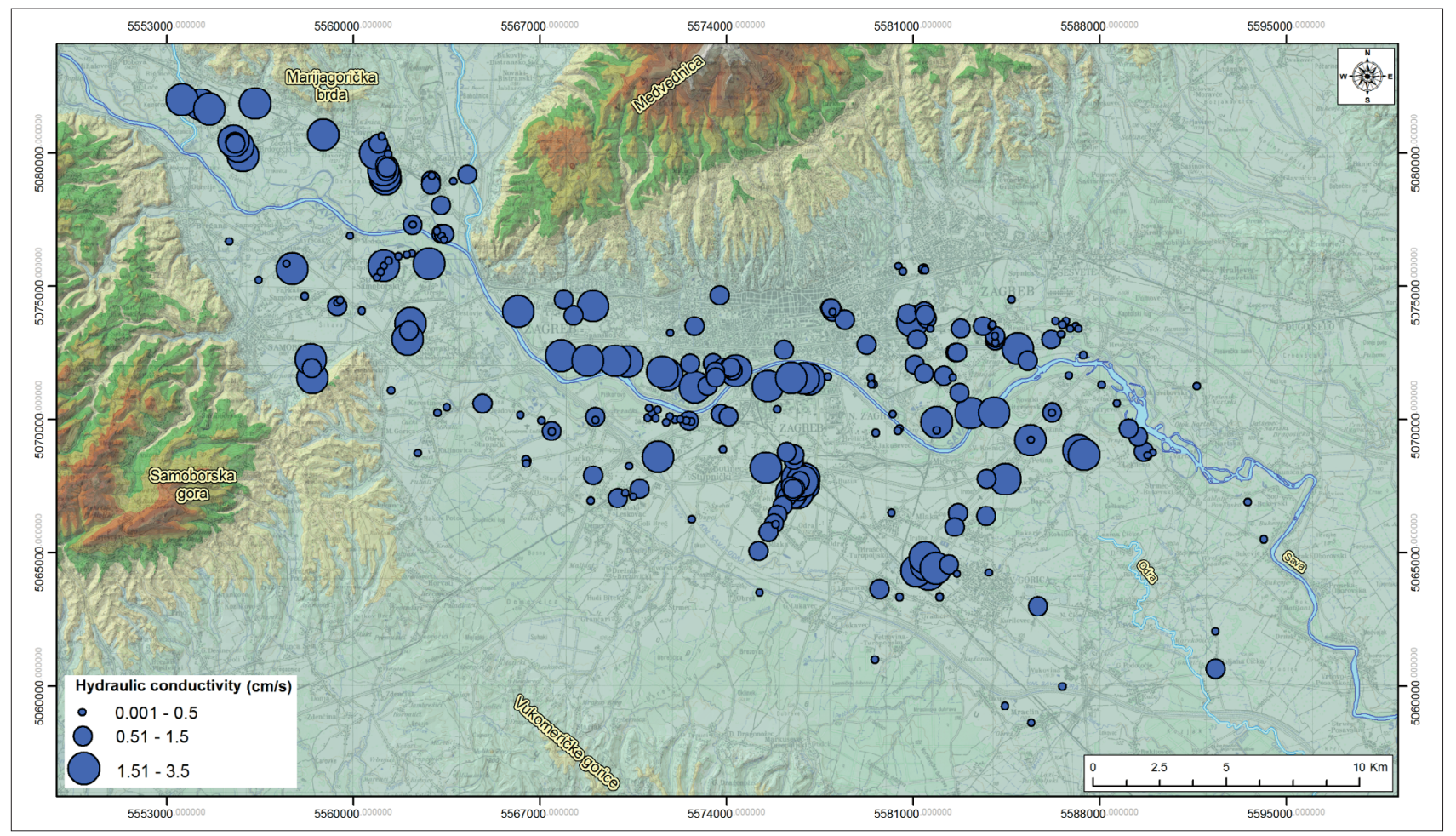

Figure 3: Hydraulic conductivity of wider Zagreb area (from Posavec et al., 2015)

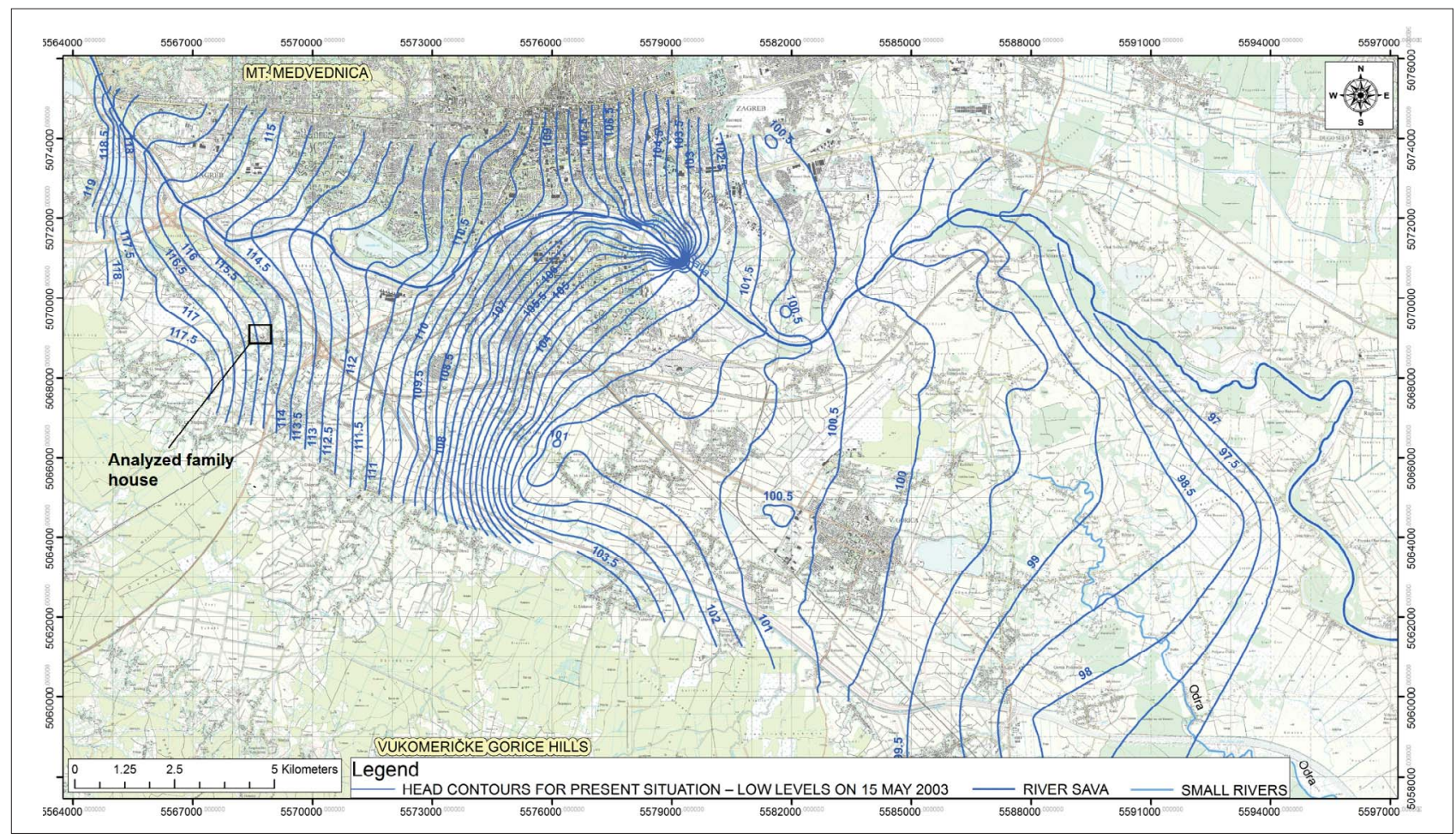

Figure 4: Head contours for Zagreb aquifer during low level period and a location of analysed building (from Posavec et al., 2015)

that typically have high values of hydraulic conductivity. (see Figure 3).

The Sava River generally maintains groundwater levels in the whole aquifer area. Dry periods and lack of precipitation in the summer months, primarily in the up- per parts of the Sava catchment area, result in long durations of low Sava water levels. In such conditions, due to drainage of the aquifer, groundwater level decreases. Low groundwater due to hydrological drought in 2003 is shown in Figure 4. 


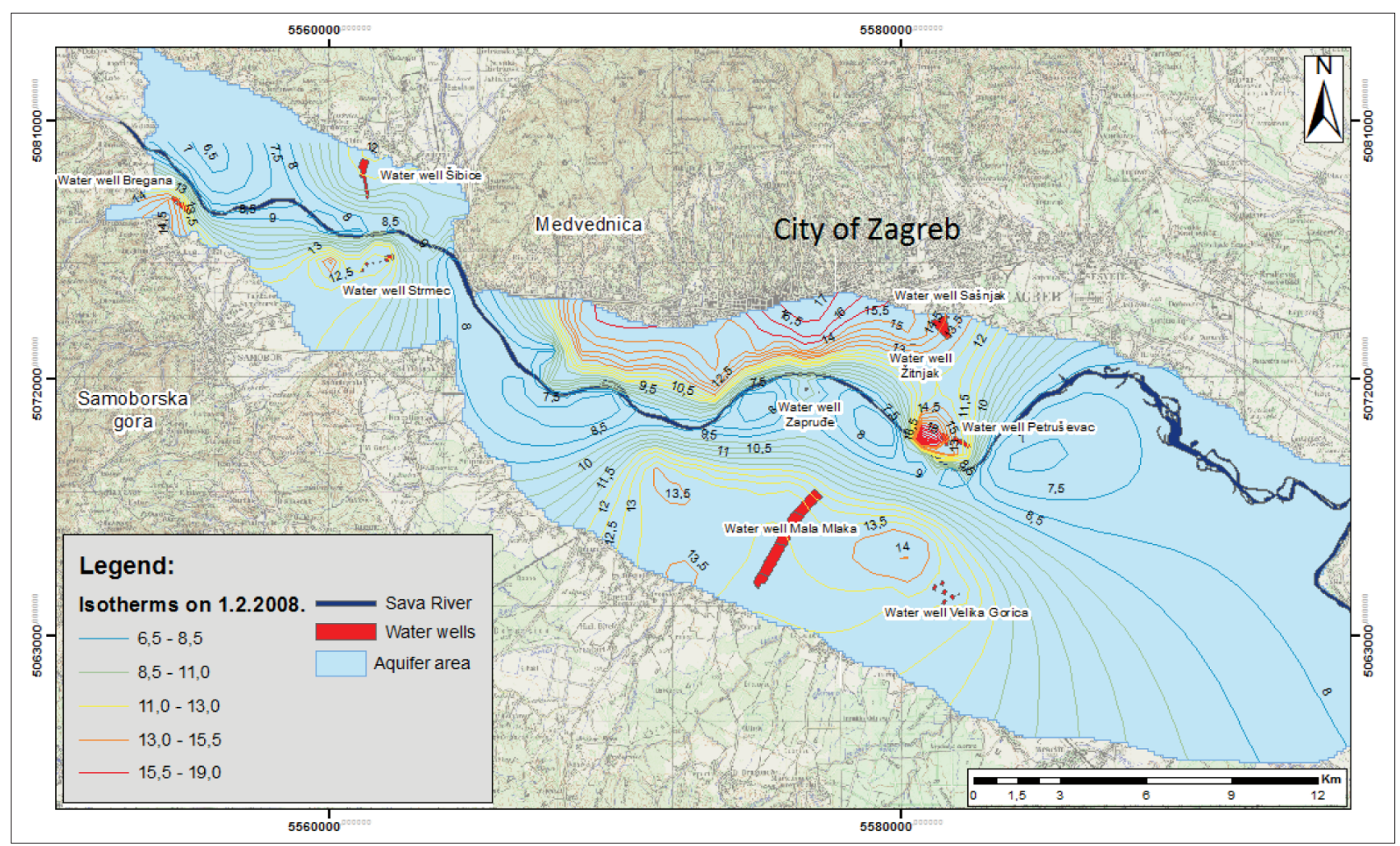

Figure 5: Minimum temperature isotherms of groundwater in wider area of Zagreb needed for modelling GWHP systems (from Kapuralić, 2013)

In the wider Zagreb area, there are about 500 piezometers. Measurements of groundwater levels are carried out by the Meteorological and Hydrological Service and Vodoopskrba i odvodnja Ltd. (a domestic water supply company). For a large number of piezometers, data is available from 1950 until today. Existing measurements showed an extremely negative trend of groundwater levels. It can be assumed that the main reasons for the lowering of groundwater levels are the deepening of the riverbed and growing exploitation of groundwater. Building a threshold for a thermal power station in the early nineties did not stop, but significantly reduced the negative trend of groundwater levels upstream of the threshold.

As described in (Kapuralić, 2013), maximal measured temperatures of groundwater are between $11.5^{\circ} \mathrm{C}$ and $26^{\circ} \mathrm{C}$, while minimal are between $6^{\circ} \mathrm{C}$ and $16.6^{\circ} \mathrm{C}$. Figure 5 shows isotherms of minimal temperatures measured in the winter period, with values in range from $7^{\circ} \mathrm{C}$ up to $18^{\circ} \mathrm{C}$. What is also important to note is that in the areas of active well fields, ground water temperatures oscillate the least. Temperature oscillations might be two to three degrees Celsius in both, summer and winter periods.

\subsection{Thermogeological aspects}

The average value of the geothermal gradient in the Pannonian Basin is $0.049{ }^{\circ} \mathrm{C} / \mathrm{m}$. This value is higher than the world average of $0.03{ }^{\circ} \mathrm{C} / \mathrm{m}$. Taking into consideration the average value for the Pannonian Basin, it was concluded that there is a positive geothermal anomaly in the area of Zagreb with more than $0.06{ }^{\circ} \mathrm{C} / \mathrm{m}$, which is probably caused by convection phenomena (Jelić, 1979). Bedrock in this area is thin which suggests that structures allowed warm fluid to rise from the depth via permeable formations or fault systems. When a geothermal gradient is elevated in a certain area, it could positively influence the sizing of the borehole heat exchanger. In previous research (Kurevija et al., 2014), it was shown that such a geothermal gradient could reduce a borehole heat exchanger's total length by $5 \%$, as compared to a calculation which neglects the geothermal gradient and only works with an undisturbed surface ground temperature.

In Zagreb, the ground is an unconsolidated mixture of clay and gravel/sand, and thermal conductivity and diffusivity changes for shallow depths depend mostly on monthly precipitation and moisture contained in the ground, as well as the thickness of the aquifer. Taking into an account values of heat diffusivity for Zagreb of $0.045 \mathrm{~m}^{2} /$ day, calculated heat conductivity of the ground at a depth of $2-5 \mathrm{~m}$ is $1.44 \mathrm{~W} / \mathrm{m}^{\circ} \mathrm{C}$ (Kurevija, 2010). By solving the sinusoidal damping function for ground temperature, it can be perceived that for a depth of $12 \mathrm{~m}$, temperature variation amplitude during the year amounts to only $0.1{ }^{\circ} \mathrm{C}$, and the undisturbed ground temperature equals $13.1^{\circ} \mathrm{C}$. Figure 6 shows seasonal oscillations of the average monthly ground temperatures that were calculated for depths from $1 \mathrm{~m}$ up to $12 \mathrm{~m}$. By using values of damping temperature amplitudes in analytical solu- 


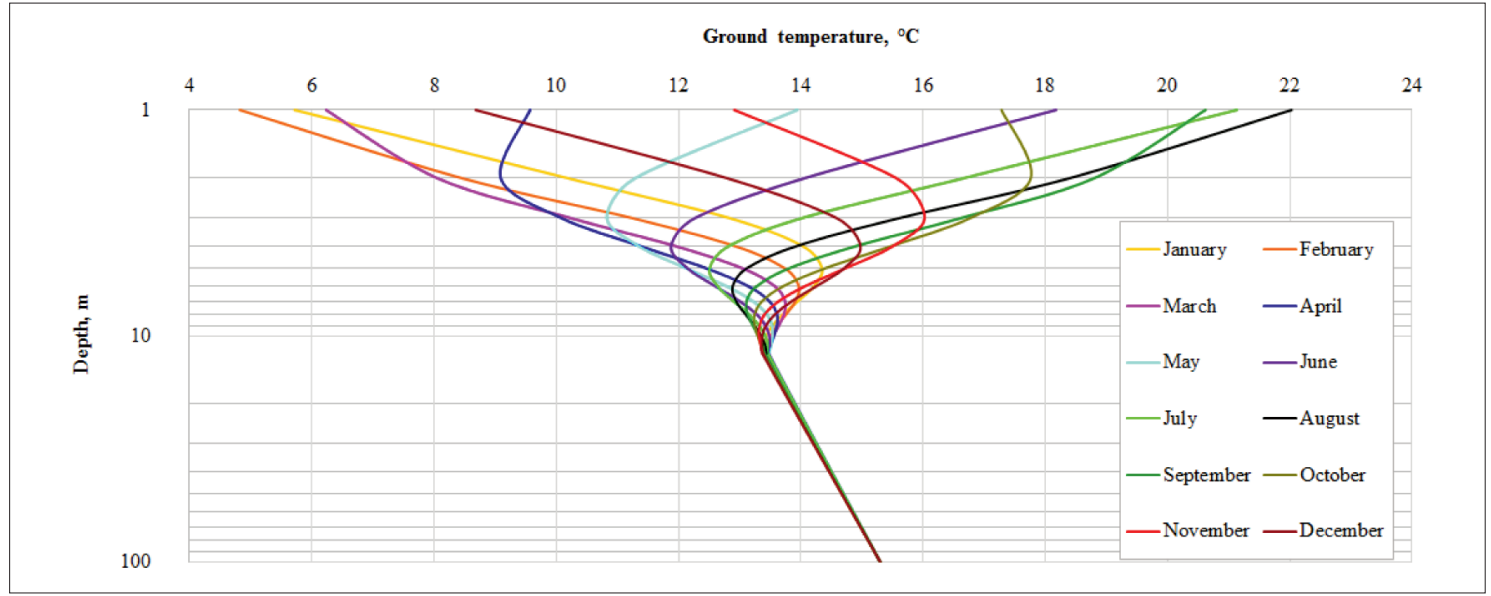

Figure 6: Calculated monthly ground temperatures for Zagreb, needed for modelling of GSHP systems (from Kurevija, 2010)

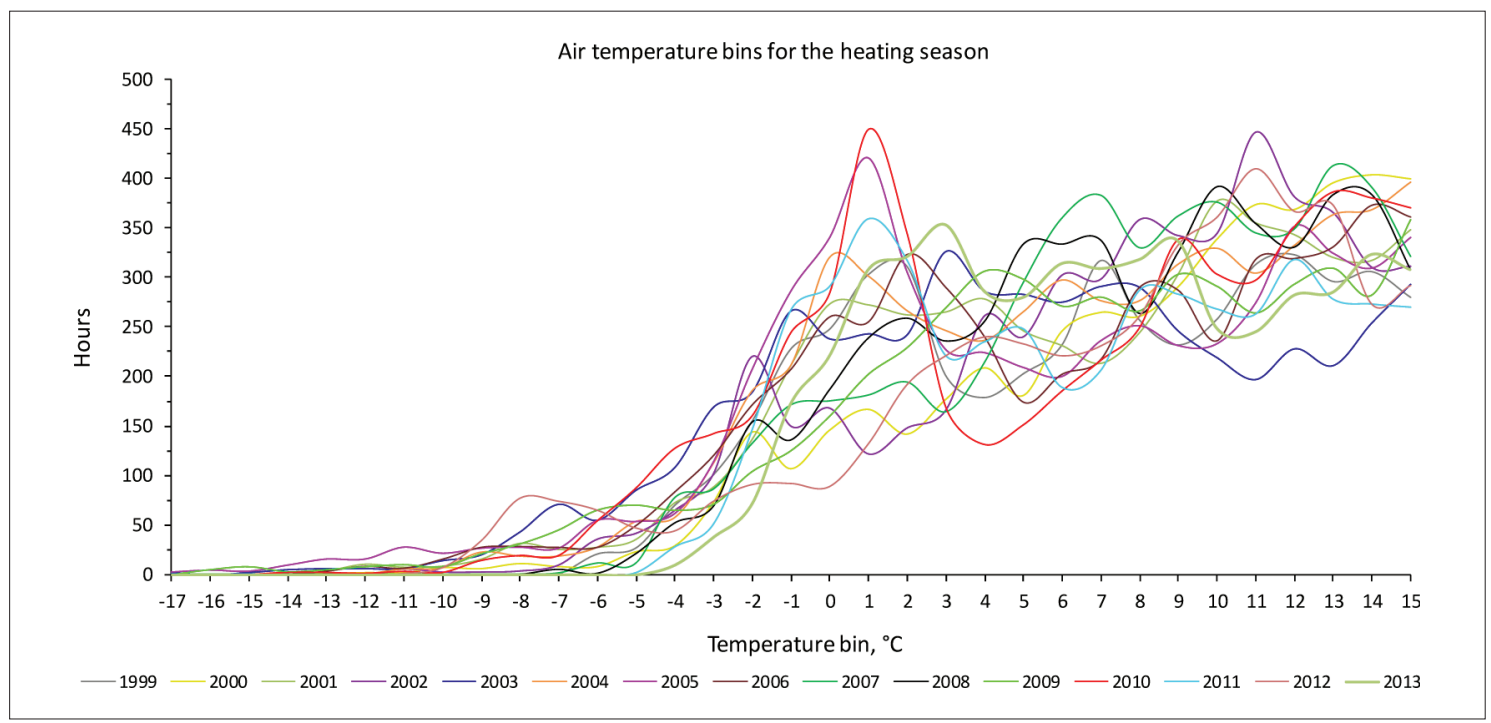

Figure 7: Annual frequency distribution of average hourly air temperature in Zagreb for period of 1999-2013, needed for modelling of ASHP system

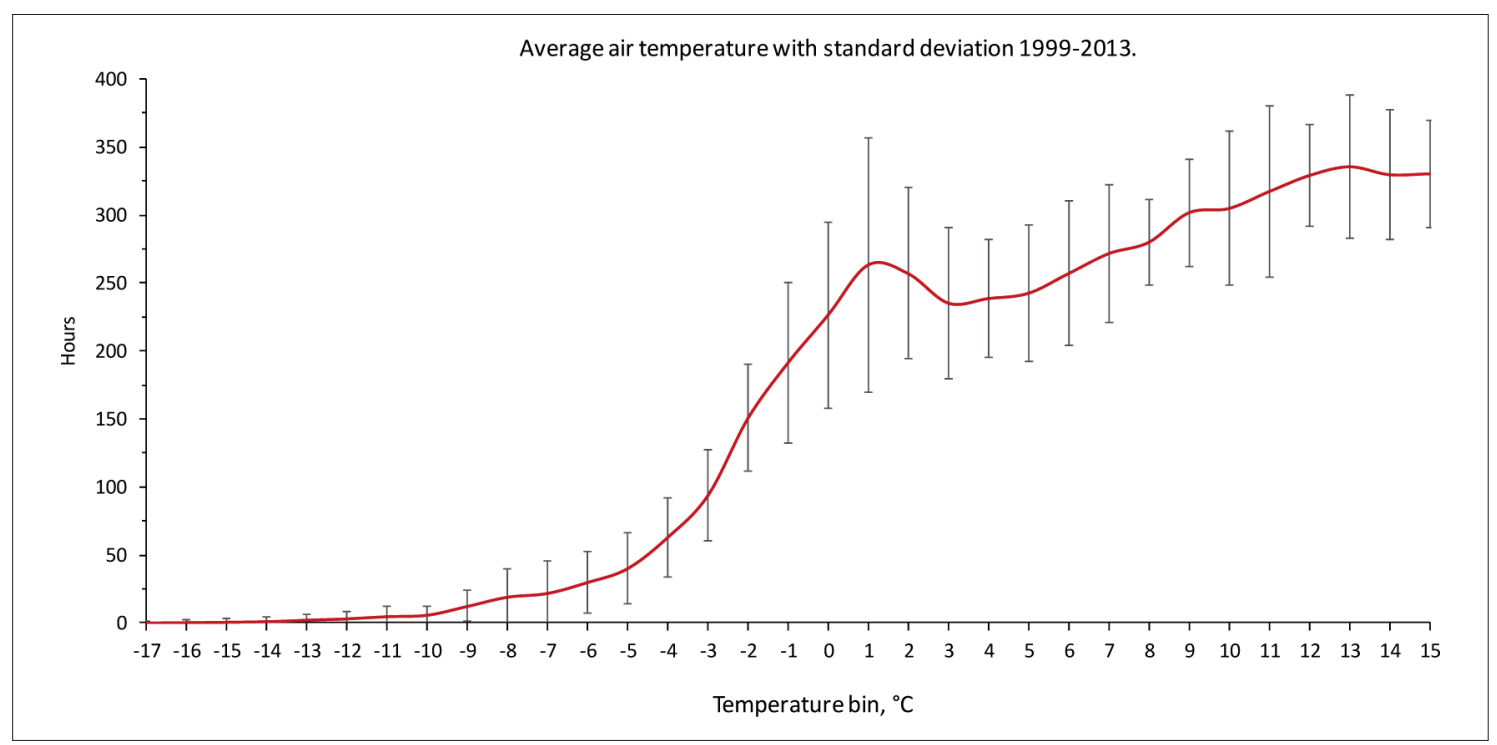

Figure 8: Average hourly air temperature with standard deviation in Zagreb for period of 1999-2013, needed for modelling of ASHP system 


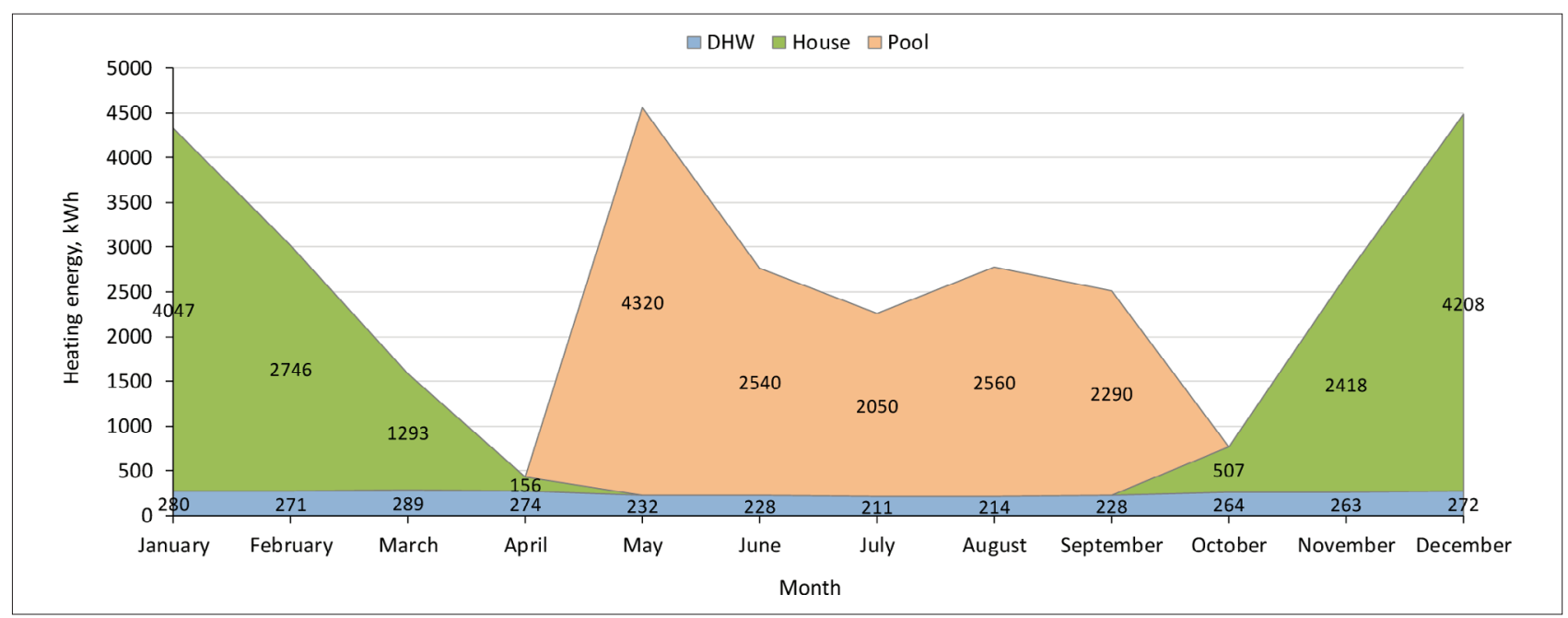

Figure 9: Building heating capacity and uses required during the year

tions, extrapolation of a ground temperature versus depth is possible, where there is no measured data. Thus, temperature oscillation at some depth can be estimated with a sinusoidal function solving the differential equation (Kurevija and Vulin, 2010). Damping depth is related to the point where yearly amplitude of ground temperature oscillation decreases for 1/e (e - Euler number) compared to the air temperature. With greater yearly air temperature oscillations, damping depth will be lower.

\subsection{Climate aspects}

Zagreb has a marine west coast climate that is mild with no dry season, and with warm summers. Heavy precipitation occurs during mild winters, which are dominated by mid-latitude cyclones. Seasonality is moderate with a mean annual temperature of $11.3^{\circ} \mathrm{C}$ and the average monthly temperature amplitude is $21^{\circ} \mathrm{C}$. In the winter time, records indicate temperatures by day reach $4.2^{\circ} \mathrm{C}$ on average, falling to $-0.7^{\circ} \mathrm{C}$ overnight. In the spring time, temperatures climb reaching $16.1^{\circ} \mathrm{C}$, generally in the afternoon with overnight lows of $7.8^{\circ} \mathrm{C}$. During the summer, average high temperatures are $25.1^{\circ} \mathrm{C}$ and average low temperatures are $15.9^{\circ} \mathrm{C}$. In the autumn, temperatures decrease achieving average highs of $15.3^{\circ} \mathrm{C}$ during the day and lows of $8.4^{\circ} \mathrm{C}$ (Gajić-Čapka and Zaninović, 2008).

Figure 7 shows average annual hourly temperature frequency distribution, which is needed to calculate seasonal energy efficiency of air-source heat pumps, as well as to calculate monthly energy needs for heating, with standard deviations versus average hourly air temperature shown in Figure 8.

\section{Case study - Analysis of residential house heating loads}

A new residential family house in Zagreb, Croatia, with a total net area of $240 \mathrm{~m}^{2}$, completely heated and cooled with renewable resource will be discussed as an example. The building is located in the Rakitje district, in the far western part of the aquifer. The building was eventually equipped in 2015 with a geothermal heat pump with shallow energy resource, in the form of three borehole heat exchangers. Since other designs were considered and a pre-feasibility study of implementation of renewable sources for heating and cooling was made, this paper will show an economical comparison of all possible designs available at the location at that time. The building has a net heated volume of $872 \mathrm{~m}^{3}$ and the outside walls have a surface area of $861 \mathrm{~m}^{2}$. The coefficient of transmission losses for the building is 369.6 $\mathrm{W} /{ }^{\circ} \mathrm{C}$, while ventilation heat losses are $125.9 \mathrm{~W} /{ }^{\circ} \mathrm{C}$, making the total heat losses coefficient of $495.5 \mathrm{~W} /{ }^{\circ} \mathrm{C}$. In Figure 9, the building heating capacity required throughout the year is shown, for different uses.

Since buildings in the wider area of Zagreb are usually sized for peak heating at an outside minimum temperature of $-15^{\circ} \mathrm{C}$, and with a maximum interior temperature of $23^{\circ} \mathrm{C}$, the heating system must have a capacity of $19.8 \mathrm{~kW}$ to cover peak loads. Along the house, the heat pump system also needs to prepare domestic heat water (DHW) and the outdoor pool with dimensions of $10 \times 4.5 \times 1.2 \mathrm{~m}$. The operating season of the pool is the 15 th of May until the 15 th of September. This requires a year-round heating concept, unlike the usual comparisons between different heat pump renewable energy sources which are often carried out for heating during winter. In this concept, an ASHP system has a better COP during the summer months for heating of the swimming pool than a geothermal source. The temperature of pool water was set at $26^{\circ} \mathrm{C}$ throughout the swimming season. An entire energy analysis of the swimming pool was performed, and the cooling needs of the building were neglected in this analysis, as they were significantly lower than the heating loads. The building heating and cooling loads were calculated according to the Croatian norm HRN EN ISO 13790. 
In Figure 10, a mechanical engineering execution design is shown. The entire family house is treated as a single heating zone, with the installation of a DHW tank as a compact concept inside the heat pump, and an additional heating circuit for the swimming pool, which is separated with a plate heat exchanger and a three-way valve. The installed heat pump was an inverter type, which means it has a scroll variable speed compressor. The advantage of an inverter heat pump is that it significantly increases the seasonal performance factor throughout the year, because the heat pump can adapt to the demand variations. Furthermore, the outlet temperature of the heat pump can be overall somewhat lower compared to a traditional design with a fixed speed com-

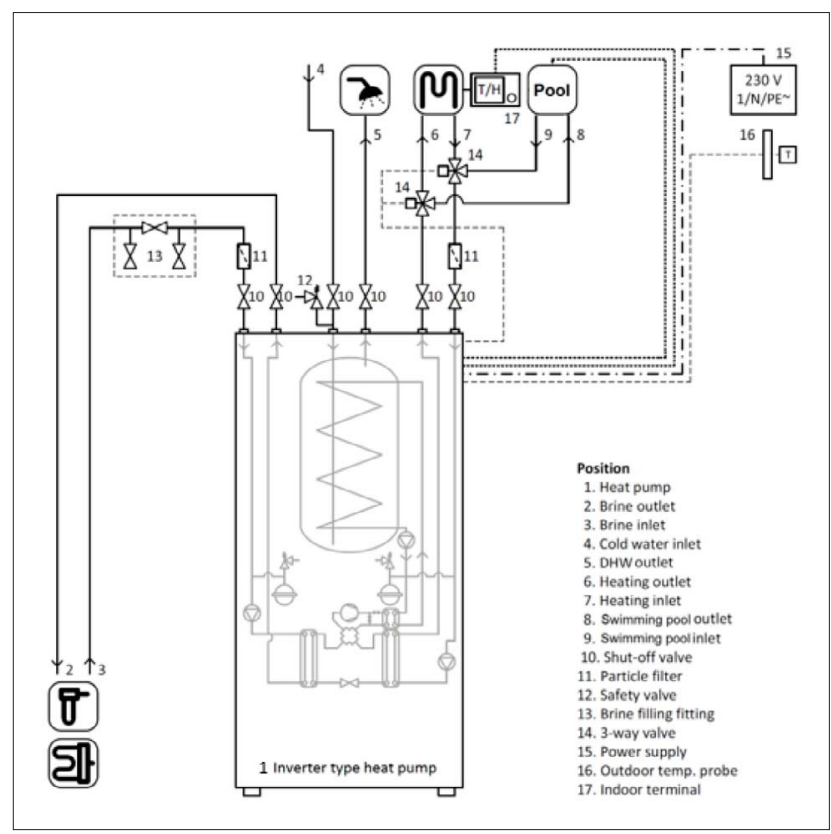

Figure 1o: Inverter geothermal heat pump - simplified mechanical engineering execution design pressor. Also, it implies the absence of a classical buffer tank in mechanical engineering design, which lowers the initial capital cost of the system (no buffer + additional shunt group of circulation pump and mixing valve). Furthermore, the no-buffer design gives better system efficiency since such implementation means a loss in energy throughout the year, since its temperature is higher during the winter and lower in the summer than the ambient temperature.

For Zagreb climate location data and building physics data, it is possible to construct the functions of heating capacity and heating energy versus the outside temperature bin, as shown in Figure 11. This approach is especially important when a hybrid heat pump system is considered where the heat pump covers only the base heating load and the substitution resource of energy must cover the peak loads. This is usually the case in colder climates when implementing the ASHP system, since the capacity of the air source heat pump drops significantly with lower outside temperatures, especially below $0^{\circ} \mathrm{C}$. To substitute the loss in capacity of the heat pump, an electric heating element must be implemented into the system, making it a monoenergetic system type since the same source of energy is required.

The cost-effectiveness of an ASHP system is directly dependent on the amount of electricity used by the substitution heating element, as this amount strongly influences the Seasonal Coefficient of Performance (SCOP) of the system.

As an example from Figure 11, it is seen that below $-5^{\circ} \mathrm{C}$, the building will consume approximately $9 \%$ of its annual heating energy requirements. At this temperature, the capacity of heat pump is $70 \%$ of the maximum required heating capacity to cover peak loads. Comparing data of the required building heating capacity from Figure 9, with the manufacturer's data of heat pump capacity versus the outside temperature, as shown in Figure

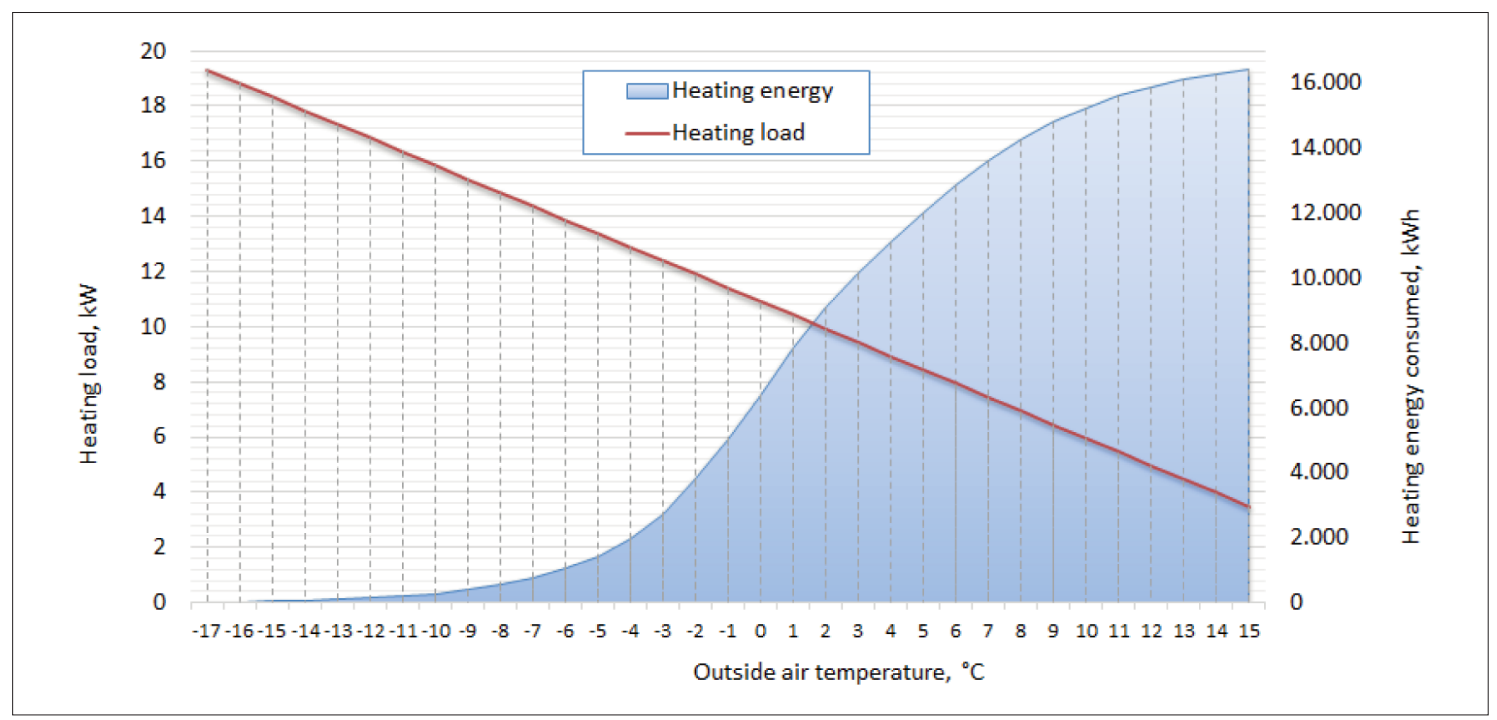

Figure 11: Correlation of project heating load and heating energy versus outside temperature bin 


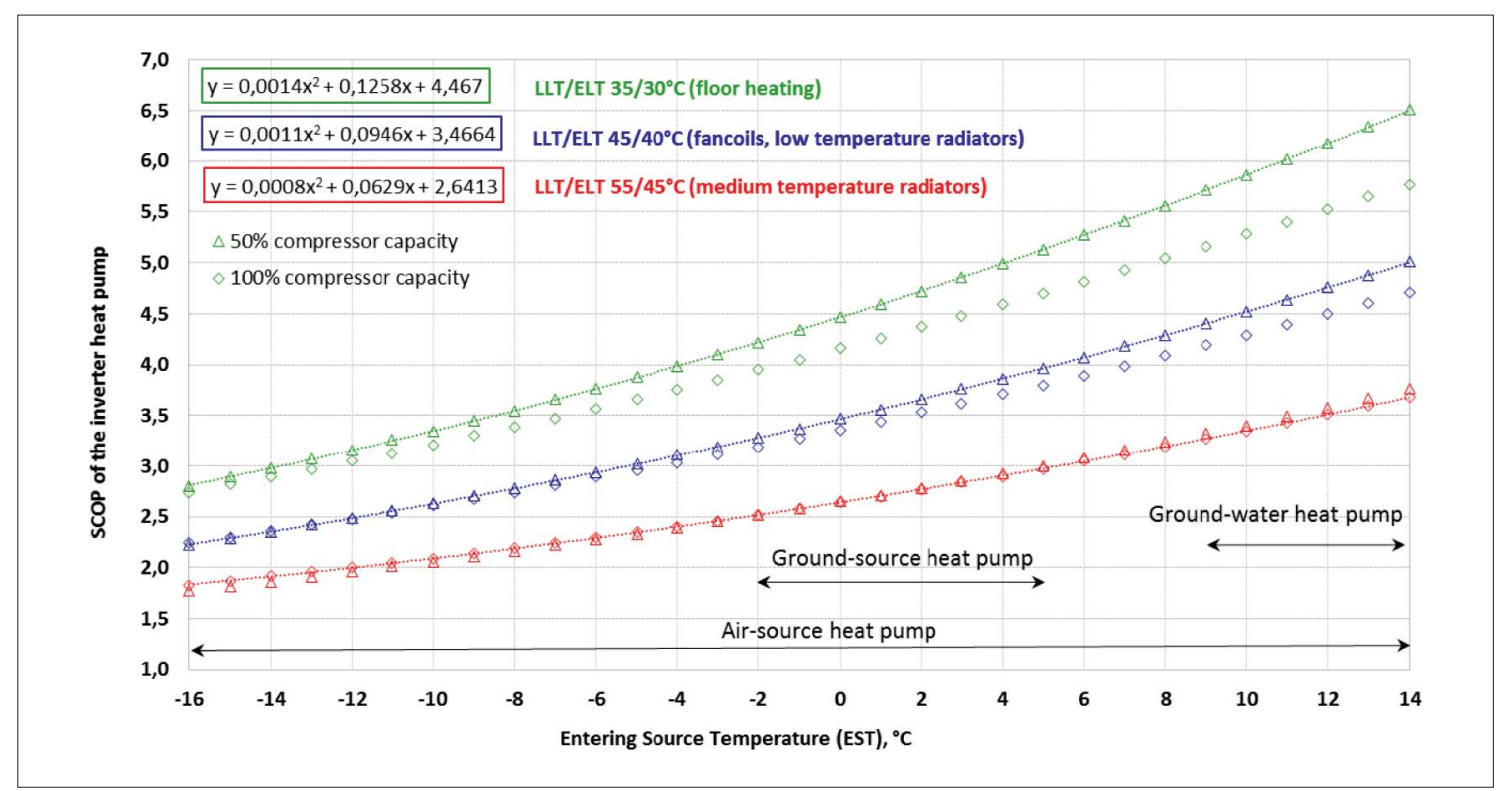

Figure 12: Heat pump SCOP as polynomial function of EST and LLT

12 (Entering Source Temperature - EST), creates the possibility to calculate SCOP for the ASHP system design, analyse full load hours of the heating element in operation, as well as compare it with other sources of energy for heat pumps, like ground heat and groundwater. It can be seen that heating capacity of the heat pump drops as a polynomial function of the second order in a function of EST. Figure 12 also shows five different distribution temperatures (Leaving Load Temperatures LLT; Entering Load Temperature - ELT), according to options to implement floor heating, fan coils or low-temperature radiators. As lower source temperature values (or evaporator side) negatively influence the SCOP of the heat pump system, the high condenser side temperature does so as well (LLT). Figure 12 shows the SCOP as a polynomial function of $\operatorname{EST}\left({ }^{\circ} \mathrm{C}\right)$ and $\operatorname{LLT}\left({ }^{\circ} \mathrm{C}\right)$ for different types of distribution systems. Multiple points for $0^{\circ} \mathrm{C}, 5^{\circ} \mathrm{C}$ and $10^{\circ} \mathrm{C}$ are dependent on the rotating speed of the compressor, from $1800 \mathrm{rpm}$ to $6000 \mathrm{rpm}$. In this analysis, the trend-line of mean values was implemented to obtain a polynomial function of the SCOP depending on EST. It is important to point out that this value of the SCOP includes energy consumption from both circulating pumps with a variable speed drive, on the source side and the load side. The analysis of different solutions of geothermal exchanger side and indoor distribution systems provide very reliable SCOP data to compare the cost-effectiveness of each heat pump system design, as will be shown in next chapter.

\section{Results of comparison model for different heat pump systems}

According to climate, technical and thermogeology data presented in the previous chapters, a comparison of different heat pump systems was carried out. Energy sources that were considered at the location are air, ground heat and groundwater. As analysis of their parameters shows, they were suitable for year-round heating and cooling processes. For ASHP, the hourly distribution of the outside temperature during the winter was still favourable enough to consider this kind of system in the final design with full coverage of peak loads. For GSHP, with undisturbed ground temperature of $13^{\circ} \mathrm{C}$ at $10 \mathrm{~m}$, and a geothermal gradient of $5.5^{\circ} \mathrm{C} / 100 \mathrm{~m}$, the borehole heat exchanger was already proven as a reliable geothermal resource for the city of Zagreb. For GWHP, there is also a long tradition of using the shallow aquifer under the city of Zagreb as an energy resource. The favourable temperature of groundwater during the entire year with values between $11-14^{\circ} \mathrm{C}$ provides the highest SCOP achievable on the heat pump.

Numerical computation and sizing of borehole heat exchangers, as a final chosen design, was carried out with commercially available software - Ground Loop Designer Premiere (GLD2009), which uses both heat transfer solutions available today; ASHRAE/Kavanaugh cylindrical source numerical model and Lund/Eskilson line source numerical model described in the introduction. The final design was constituted of 3 boreholes, each per $100 \mathrm{~m}$, with a spacing distance of $7 \mathrm{~m}$ between them. The Thermal Response Test measurements (TRT) show that the effective thermal conductivity coefficient of a $100 \mathrm{~m}$ borehole exchanger is $1.80 \mathrm{~W} / \mathrm{m}^{\circ} \mathrm{C}$. The heat exchanger implemented was a double U-loop pipe PE100 SDR11 D32 and grouting was performed with a thermal active cement with a rated conductivity coefficient of $2.0 \mathrm{~W} / \mathrm{m}^{\circ} \mathrm{C}$.

Figure 13 shows a simulation model carried out with commercially available software Ground Loop Designer 2009 (GLD2009) with the method described in (Kavanaugh 1997; Eskilson 1987). Geothermal heat pump 


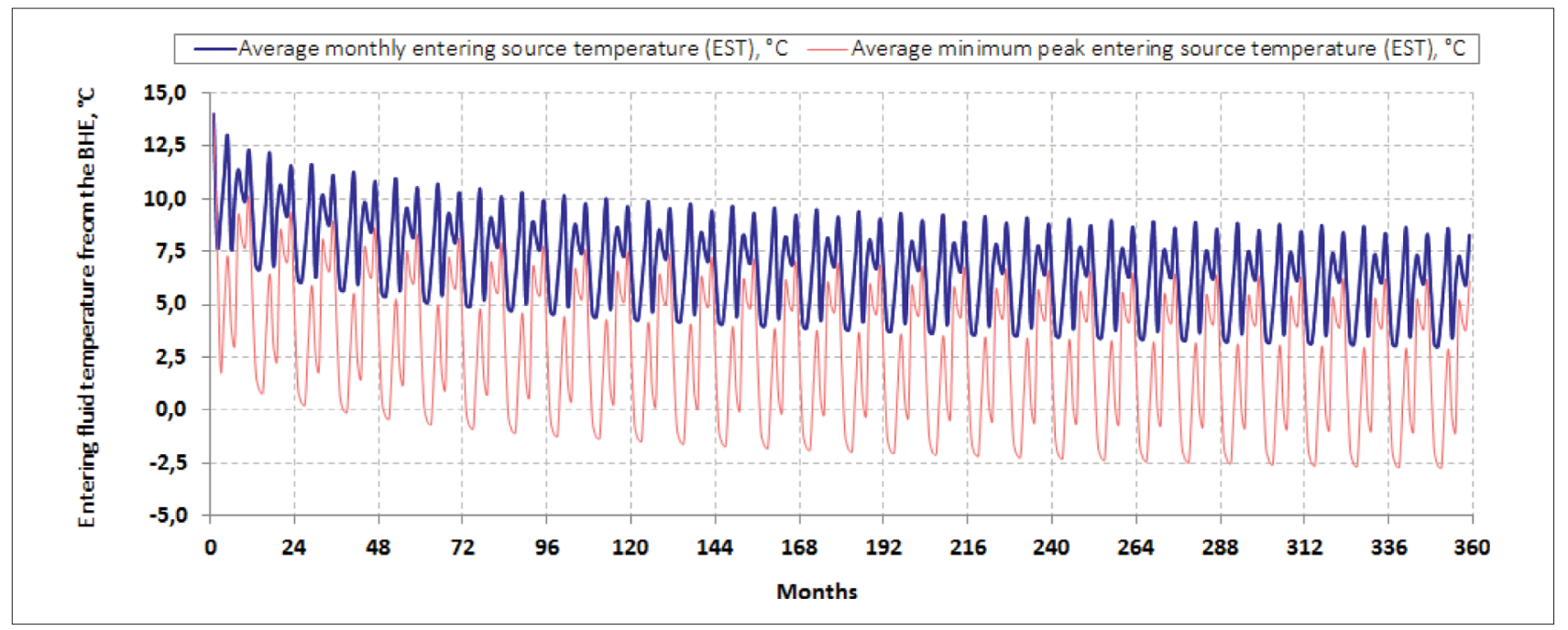

Figure 13: Long term operation analysis of the BHE entering source temperature, simulated with GLD20o9

systems should be sized for at least a 30 -year period of operation to minimize the thermal interference effects between adjacent boreholes and account losses due to sub-cooling of the ground. The principle of multi-year sizing is not to allow the minimum temperature of the working fluid during the peak-load conditions to approach its freezing point. The mean monthly temperature of the working fluid under average base-load conditions should not drop significantly below $0^{\circ} \mathrm{C}$ over the design life of the system. This leads to oversized systems in the first years of utilization (a more efficient system with a higher SCOP) and slightly undersized in last years (lower SCOP). Also, during the thermal response testing it is advisable to carry out a novel Step Thermal Response Test (STRT) which can show the relationship between the entering source temperature (from the ground to the heat pump) and the heat extraction rate per meter of the borehole (Kurevija et al., 2017; 2018)

However, the entering source temperature due to the short peak load conditions in January and February are commonly in the range of -4 to $0{ }^{\circ} \mathrm{C}$. In Figure 13, two sinusoidal curves are shown: the red curve represents the minimum monthly temperatures under heating short peak load conditions. The blue curve shows the evolution of fluid temperature under the monthly base load. As it is visible from Fig. 13, at the end of the thirty-year period, the typical base heating load working fluid temperatures are approximately $+3^{\circ} \mathrm{C}$ for the coldest months, as compared to $+7^{\circ} \mathrm{C}$ in first years of operation. Under short heating peak load conditions, the average working fluid temperatures drop as low as $-2.5^{\circ} \mathrm{C}$ during the coldest months after 30 years, as opposed to the minimum of $+2.0^{\circ} \mathrm{C}$ in the first years of operation.

Figure 14 shows the final results from the simulation of each proposed system. A natural gas condensing boiler was taken as a comparative model, since the decision on whether to implement renewable heat pump systems depends on the amount of savings it guarantees, as well as the difference between the initial capital costs. The cost of natural gas in the Croatian market is averaged at $48.74 € / M W h$ (VAT included, July 2017). The mean electricity cost (daytime and nighttime tariff interpolation) is currently averaged at $115.23 € / \mathrm{MWh}$ (VAT included, July 2017). It can be seen that for the most effi-

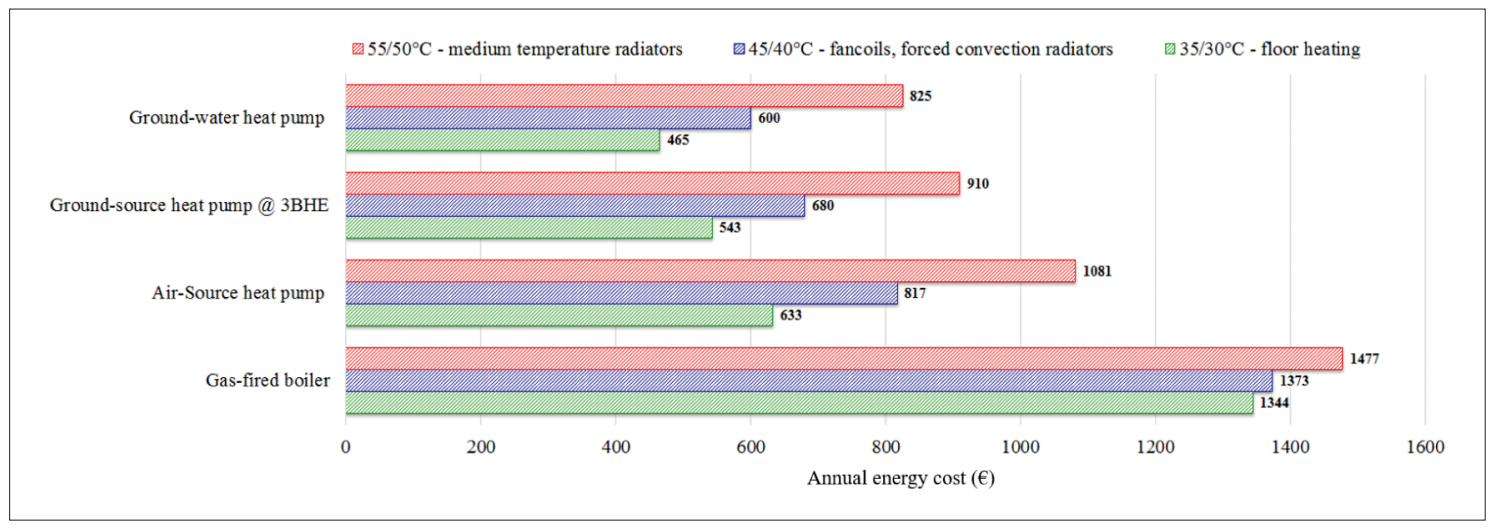

Figure 14: Annual energy cost simulation of three various inverter heat pump system compared to traditional gas-fired boiler system (in EUR) 


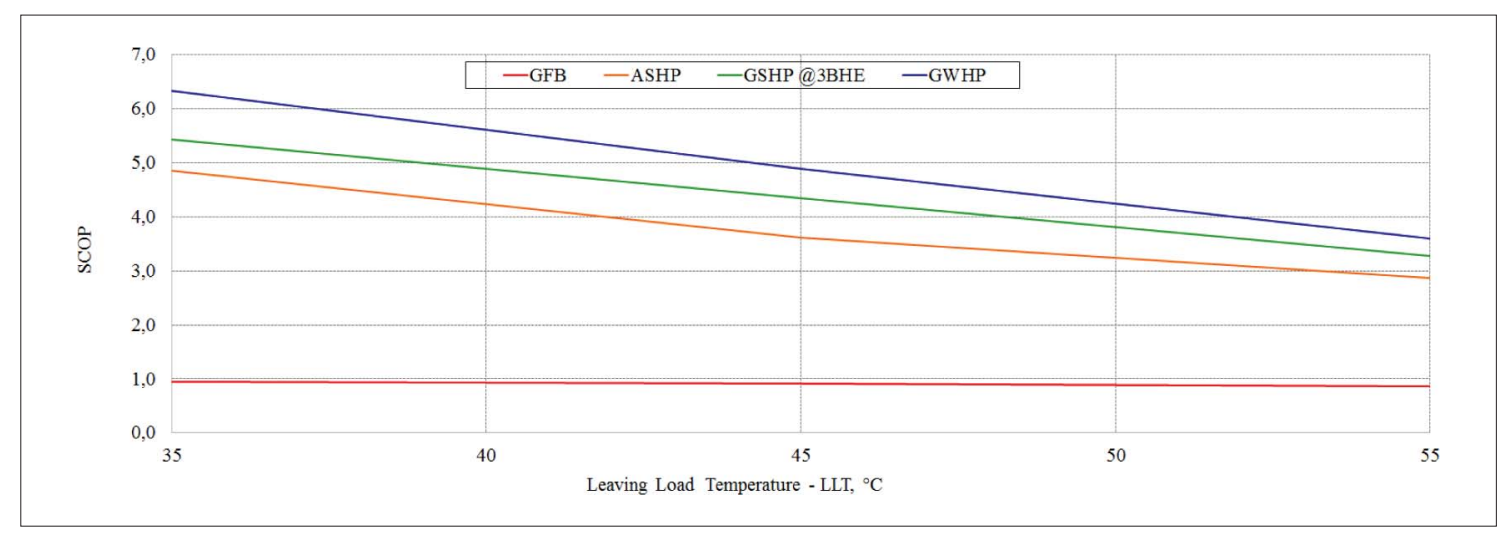

Figure 15: SCOP values for each heat pump system analysed compared to natural gas fired boiler

cient system of floor heating (LLT $\left.=35^{\circ} \mathrm{C}\right)$ which was implemented in the family house, the savings of the ASHP compare to a natural gas boiler (AFUE - Annual fuel utilization efficiency of $92 \%$ ) offers a $48.5 \%$ reduction in annual energy costs, while the SCOP on an annual basis is 4.40. A GSHP system with three borehole heat exchangers offers a $59.7 \%$ reduction in costs, with a SCOP of 5.65. Using groundwater via production + injection wells, gives the most economical case with a $63.4 \%$ reduction in costs with the most efficient system with a SCOP of 6.23. For example, if higher temperature distribution systems were decided to be used, like fan coils with LLT of $45^{\circ} \mathrm{C}$, or radiators with LLT of $55^{\circ} \mathrm{C}$, system efficiency and cost-effectiveness would gradually deteriorate. All heat pump systems would then have little benefits compared to each other because of the high temperature of compression. SCOP versus LLT values are shown in Figure 15 for each system.

\section{Conclusion}

This paper analysed the seasonal performance factor for different heat pump systems in the moderate climate of Zagreb, the Republic of Croatia. It is usually perceived that air-source heat pumps are not efficiently applicable in climates with cold winters, as opposed to other types of heat pumps such as ground-source or groundwater types. Since heat pumps are often installed in higher-class residential housing, it usually requires year-round energy needs, mostly due to secondary heating of outdoor or indoor swimming pools. In such cases, as presented in this paper, ground-source and groundwater systems lose much of the techno-economic advantages compared to air-source heat pumps due to more favourable conditions in the summer-time heating with air. The analysis showed that the overall SCOP is very similar for all the systems, independently of the distribution temperature used (floor heating, fancoils, radiators). This phenomenon could be explained with the fact that subcooled ground slowly regenerates after the winter period, as opposed to air temperatures which are higher during the rest of the year. Therefore, the techno-eco- nomical favourability of which heat pump system to implement, directly depends on the amount of heating energy utilised during the spring-summer season. In classical concepts where there is no heating consumption during the spring-summer months, the economic favourability of the ASHP system tapers off significantly compared to ground-source and ground-water designs, since it operates with much lower temperatures on average during the year. Furthermore, if cooling needs are significant, the ASHP system economy worsens even more since subcooled ground or groundwater offers much more favourable temperature conditions. Therefore, planning an efficient heat pump system demands understanding not only the mechanical engineering design linked to climate data, but a series of geological, thermogeological and hydrogeological data for a certain location. Further study should include more detailed overall economic analysis, including the payback period for various systems.

\section{References}

Brkić, Ž., (1999): Napajanje aluvijalnih vodonosnika sjeverne Hrvatske kroz slabije propusne krovinske naslage (Alluvial aquifer recharge through semipermeable covering deposits in northern Croatia). $\mathrm{PhD}$ thesis (in Croatian), Faculty of Mining, Geology and Petroleum Engineering, University of Zagreb, Croatia

EN 14511 (2004): Air conditioners, liquid chilling packages and heat pumps with electrically driven compressors for space heating and cooling.

EN ISO 13790: 2008 (2008): Energy performance of buildings-Calculation of energy use for space heating and cooling. International Standard Organisation.

Eskilson, P., (1987): Thermal analysis of heat extraction boreholes [dissertation]. Lund, Sweden:University of Lund;

Gajić-Čapka, M., Zaninović, K. (2008): Climate of Croatia. In: Zaninović, K. (ed.): Climate atlas of Croatia. Meteorological and Hydrological Service of Croatia, Zagreb, pp. 13-17.

Jelić, K. (1979): Termičke osobine sedimentacionog kompleksa jugozapadnog dijela Panonskog bazena, PhD thesis (in 
Croatian), Faculty of Mining, Geology and Petroleum Engineering, University of Zagreb, Croatia

Kavanaugh, S.P., Rafferty K. (1997): Ground-source heat pumps: Design of geothermal systems for commercial and institutional buildings. Atlanta, USA: American Society of Heating, Refrigeration and Air-conditioning Engineers (ASHRAE), Inc. pp.442.

Kapuralić, J. (2013): Defining the impact of temperature oscillation of Sava river and geothermal anomaly on the temperature oscillation of groundwater in Zagreb and Samobor aquifer. Master's Thesis. Zagreb, Faculty of Mining, Geology and Petroleum Engineering, University of Zagreb. (in Croatian)

Kurevija, T., Strpić, K., Koščak-Kolin, S. (2018): Applying petroleum the pressure buildup well test procedure on thermal response test - A novel method for analyzing temperature recovery period. Energies, 1,12, 366.

Kurevija, T., Macenić, M., Strpić, K. (2018): Steady-state heat rejection rates for a coaxial borehole heat exchanger during passive and active cooling determined with the novel step thermal response test method. The Mining-GeologyPetroleum Engineering Bulletin (Rudarsko-geološkonaftni zbornik), 33, 2, 61-71.

Kurevija, T., Strpić, K. (2018): Hydraulic and thermogeological design differences between two-loop vertical and inclined coaxial borehole heat exchangers. Renewable energy, 117, 314-323.

Kurevija, T., Macenić, M., Borović, S. (2017): Impact of grout thermal conductivity on the long-term efficiency of the ground-source heat pump system. Sustainable Cities and Society, 31, 1-11.

Kurevija T., Vulin D. (2010): Determining undisturbed ground temperature as part of shallow geothermal resource assessment. The Mining-Geology-Petroleum Engineering Bulletin (Rudarsko-geološko-naftni zbornik), 22, 27-36.

Kurevija, T. (2010): Energetsko Vrednovanje Plitkih Geotermalnih Potencijala Republike Hrvatske (Energetic evaluation of the shallow geothermal potential in the Republic of Croatia), PhD thesis, Faculty of Mining, Geology and
Petroleum Engineering, university of Zagreb, Croatia, pp. 183

Kurevija T., Vulin, D., Macenić, M. (2014): Impact of geothermal gradient on ground source heat pump modelling. The Mining-Geology-Petroleum Engineering Bulletin (Rudarsko-geološko-naftni zbornik),28, 39-45

Parlov, J., Nakić, Z., Posavec, K., Bačani, A. Origin and dynamics of aquifer recharge in Zagreb area, The Fifth International Scientific Conference on Water, Climate and Environment, BALWOIS 2012, Ohrid, Makedonija, 28.05.02.06.2012.

Posavec, K. (2006): Identifikacija i prognoza minimalnih razina podzemne vode zagrebačkoga aluvijalnog vodonosnika modelima recesijskih krivulja (Identification and prediction of minimum ground water levels of Zagreb alluvial aquifer using recession curve models). Phd Thesis. Zagreb, Faculty of Mining, Geology and Petroleum Engineering, University of Zagreb. (in Croatian)

Posavec, K., Jović, V., Brkić, B., Kolarić, D. And Bekić, D. (2015): Zagreb on Sava - Identification of influence of conceptual designs multipurpose hydrotechnical system planning, protection and usage of Sava River (options 0, 1 and 2) on groundwater of Zagreb and Samobor-Zaprešić aquifers, Croatian conference on water with international participation. Croatian waters on investment wave. Opatija, 20th-23rd May.

Šikić, K., Basch, O., Šimunić, A., (1978): Basic geological map of SFRJ. Zagreb: Croatian Geological Survey.

Velić, J., Durn G. (1993): Alternating Lacustrine-Marsh Sedimentation and Subaerial Exposure Phases during Quaternary: Prečko, Zagreb, Croatia. Geologia Croatica, 46, 1, 71-90.

Velić, J., Saftić B. (1991): Subsurface Spreading and Facies Characteristics of Middle Pleistocene Deposits between Zaprešić and Samobor. Geološki vjesnik, 44, 69-82.

Vujević, M., Posavec, K. (2018): Identification of groundwater level decline in Zagreb and Samobor-Zaprešić aquifers since the sixties of the twentieth century. The Mining-Geology-Petroleum Engineering Bulletin (Rudarsko-geološko-naftni zbornik), 33, 4, 55-64. 


\section{SAŽETAK}

\section{Usporedba učinkovitosti dizalica topline korištenjem različitih obnovljivih izvora energije: Analiza obiteljske kuće na području grada Zagreba}

Šire područje glavnoga grada Republike Hrvatske, Zagreba, pokazuje znatan potencijal za primjenu geotermalnih dizalica topline, kako u stambenome sektoru, tako i za poslovne zgrade. Termin geotermalne dizalice topline često opisuje različite izvedbe izmjenjivača topline, od sustava iskorištavanja topline podzemnih voda, do tla kao izvora topline $\mathrm{u}$ izvedbi plitkih horizontalnih te bušotinskih izmjenjivača. Zagrebačko područje pokazuje posebno povoljne hidrogeološke i termogeološke parametre, čime je omogućena ugradnja i iskorištavanje različitih sustava izmjenjivača topline za grijanje i hlađenje stambenih i poslovnih prostora. Analiza energije te ekonomske prednosti grijanja i hlađenja korištenjem dizalica topline (izvori topline: zrak, tlo ili podzemne vode) izrađena je za grad Zagreb. Kod stambenih objekata često postoji potreba za rad dizalice topline kroz cijelu godinu, s obzirom na to da je primijećen porast broja projekata s prisutnim vanjskim bazenima. Različiti autori proučavali su i uspoređivali troškove grijanja tijekom zimskoga perioda za različite izvedbe dizalica topline. Međutim, vanjski bazeni ponekad zahtijevaju tijekom perioda proljeće - ljeto - jesen toplinske energije koliko i stambeni objekt u periodu jesen - zima - proljeće. S obzirom na to da su temperature zraka tijekom perioda proljeće - ljeto pogodnije od temperatura pothlađenoga tla ili podzemne vode, dizalice topline sa zrakom kao izvorom topline, u slučaju grijanja kroz cijelu godinu, mogu nadoknaditi ekonomski nepovoljan toplinski množitelj (COP) koji se javlja tijekom najhladnijih dana tijekom zimskoga perioda. Na primjeru stambenog objekta obiteljske kuće, u fazi izgradnje izrađena je tehnoekonomska analiza usporedbom sezonskoga toplinskog množitelja (SPF) za različite izvedbe sustava dizalice topline pod pretpostavkom grijanja kroz cijelu godinu.

\section{Ključne riječi:}

plitka geotermalna energija, dizalica topline, termogeologija, bušotinski izmjenjivači topline, podzemne vode

\section{Author's contribution:}

Marija Macenić (mag. ing. min.) and Tomislav Kurevija (Assoc. Prof., PhD) initialized the idea, lead the research, performed calculations and wrote the paper. Josipa Kapuralić (mag. ing. geol.) helped with hydrogeological background, formulating text and the compiled Methods section. 